\title{
弾性波探査試験に基づく杭健全性の合理的評価法

\author{
REASONABLE EVALUATION OF PILE SOUNDNESS \\ BASED ON PILE INTEGRITY TEST
}

\author{
勝二理 智*, 藤 森 健 史**
}

Michito SHOJI and Takeshi FUJIMORI

\begin{abstract}
When existing piles are reused, they are inspected using the pile integrity test (PIT) to judge whether they are appropriate for reuse. The evaluation of pile soundness heavily depends on the experience of PIT examiners. This paper describes the objective and quantitative evaluation method for pile soundness using PIT. The major findings of the study are summarized as follows. 1) The size of pile crack depends on the amplitude characteristics of PIT waves. 2) The size of pile crack can be evaluated using proposed "crack factors" that are calculated from the quantified values of the amplitude characteristics.
\end{abstract}

Keywords : Existing pile, Soundness evaluation, Pile integrity test, Crack factor, Field measurement 既存杭，健全性評価，杭の弾性波探查試験，損傷係数，現場計測

\section{1. 序論}

主に都市部において建替え需要が年々増加する傾向にあるなかで, 既存杭を活用して新たな杭基礎建物を建築することは, 解体作業や 残材搬出量縮減に伴う環境負荷低減，工期短縮，ローコスト化等の 利点を期待できる。こうした既存杭の再利用においては, 杭体の健 全性を確認することが不可欠となる。「既存杭利用の手引き」 ${ }^{1)}$ れば, 健全性に関する調查項目として,1) 断面状況 (寸法, 配筋等), 2) 損傷状況（ひび割れの深さや程度）が挙げられている。1)につい ては，杭頭目視調査により確認できる。2)については，杭頭目視や ボアホールカメラにより杭を直接観察する方法, 杭の弾性波探査試 験等の非破壊試験による方法がある ${ }^{2,3)}$ 。

杭の弾性波探查試験（Pile integrity test, PIT）はその簡便さから, 既存杭全数に対して実施されることが多く, 杭の健全性を評価寸る 上で重要な試験となっている。もともとは, 米国や欧州において, 場所打ち RC 杭の施工後の品質確認を目的として考案された試験で あるが, 日本では 1995 年兵庫県南部地震後の杭の被害調查に用いら れたのを契機に広まった例えば4-9)。現在では，前述したように既存杭 の再利用時の健全性評価にも活用されている ${ }^{10,11)}$ 。この試験の課題 として, ひび割れの有無や深さを概水定可能ではあるが, 経験に 基づく高度な判断が必要であり,評価結果が個人の技量に左右され, 健全性の定量的な評価が困難であることが挙げられる。杭の弾性波 探查試験の有用性を高めるためには, 試験結果を合理的に判断し, 杭の健全性を定量的に評価できる手法の構築が望まれる。

上記より, 本研究では, はじめに試験結果の分析や 3 次元有限要 素法を用いた解析的な検討により, 杭の弾性波探査試験の課題を整 理し,試験により得られる波形の振幅特性について評価した。次に,
それらの結果に基づいて, 弾性波探查試験の結果を用いて, 杭の健 全性を合理的に評価できる指標（損傷係数）を新たに提案した。さ らに，提案した損傷係数について，損傷杭を用いた実験や実建物で の現場計測結果により妥当性を検証した。

\section{2. 杭の弾性波探査試験の概要と課題}

\section{1. 試験の概要と原理}

杭の弾性波探査試験の概要を Fig. 1 に示す。試験装置は, 計測器, 加速度センサーおよび八ンマーから構成されている。試験では，杭 頭をハンマーで軽打し低ひずみの弾性波を発生させ，杭体からの反 射波を杭頭に取り付けたセンサーで計測する。微小なひずみを伴う 弾性波動の伝播を考えた場合, 杭は棒状の弾性体とみなせるので, 杭の振動は, 一次元の波動伝播として以下の式(1), (2)で表される ${ }^{12)}$ 。

$$
\frac{\delta^{2} u}{\delta x^{2}}-\frac{1}{c^{2}} \times \frac{\delta^{2} u}{\delta t^{2}}=0, c=\sqrt{\frac{E}{\rho}}
$$

ここで, $u$ : 杭頭での振動変位, $x$ : 杭頭からの深さ, $t:$ 時間, $c$ : 杭体中の波動伝播速度, $E$ : 杭の弾性係数, $\rho$ : 杭の密度。Fig. 2 の ように途中で断面が変化する杭において, 杭頭打撃により発生する 波動は杭先端方向に伝播し $\left(f_{1}\right)$, 断面変化位置で一部反射して杭頭 へ向かい $\left(g_{1}\right)$, 残りは透過して杭先端へ向かう $\left(f_{2}\right)$ 。このとき, $f_{1}$, $g_{1}, f_{2}$ は以下の式(3)-(5)で表される。

$$
f_{1}=A_{1} e^{i p\left(t-x / c_{1}\right)}, \quad g_{1}=B_{1} e^{i p\left(t+x / c_{1}\right)}, \quad f_{2}=A_{2} e^{i p\left(t-x / c_{2}\right)} \quad \text { (3), (4), (5) }
$$

また, 断面変化位置での変位と応力の連続条件は, 以下の式(6)-(7) で表される。
* (株)大林組技術研究所工修

** (株大林組技術研究所 博士 (工学) 
$\left|f_{1}+g_{1}\right|_{x=0}=\left|f_{2}\right|_{x=0}$

$E_{1} S_{1}\left|\frac{\partial\left(f_{1}+g_{1}\right)}{\partial x}\right|_{x=0}=E_{2} S_{2}\left|\frac{\partial f_{2}}{\partial x}\right|_{x=0}$

ここで, 断面変化の前後で杭の弾性係数 $E$ と波動伝播速度 $c$ が一 定とすると, 波動の反射率 $R$ および透過率 $T$ は, 杭の断面積 $S$ を用 いて以下の式(8), (9)で表わ寸ことができる。

$$
R=\frac{B_{1}}{A_{1}}=\frac{S_{1}-S_{2}}{S_{1}+S_{2}}, \quad T=\frac{A_{2}}{A_{1}}=\frac{2 S_{1}}{S_{1}+S_{2}}
$$

断面拡大部においては, $S_{1}<S_{2}$ で $R<0$ となるため, 杭頭打撃と逆 符号の振幅が得られる。ひび割れのような断面縮小部においては, $S_{1}>S_{2}$ で $R>0$ となるため, 杭頭打撃と同符号の振幅が得られる。ま た, 杭先端では $S_{2}=0$ で $T>0$ となるため, 杭頭打撃と同符号の振幅が 得られる。以上より, Fig. 1 のようにひび割れがある杭の波形には, 杭頭打撃, 杭先端反射, ひび割れ反射による振幅が同方向に生じ, それらは慣例的に負側に描かれる。

\section{2. 試験による杭の健全性評価の課題}

場所打ち RC 杭での試験により得られた実測波形を Fig. 3 に示す。 図の横軸は杭頭からの鉛直方向深さ, 縦軸は杭頭打撃の最大振幅で 正規化した振幅である。Fig. 3c は 1995 年兵庫県南部地震により建 設途中で被災した杭での試験波形であり，ボアホールカメラにより ひび割れ観察が行われ,ひび割れの位置(杭頭からの鈆直方向深さ)
とその幅が明らかになっている ${ }^{6,8)}$ 。

新設杭で得られた波形 Fig. 3a では, 杭頭打撃と杭先端反射の振幅 のみが生じ，その間に負側に振幅が生じていないことから，健全な 杭と判断できる。Fig. 3b も新設杭の波形であるが, Fig. 3a と異なり, 杭頭打撃と杭先端反射の間にわずかではあるが 0 軸を負側に超えた 振幅をいくつか確認できる。これらは，鉄筋の振動や杭の孔壁面の 粗さにより生じた振幅であり，ひび割れを示すものではなく，試験 上のノイズと解釈されるが，技術者が経験に基づき定性的に判断し ているため，その判断がばらつくことは避けられない。続いて，損 傷杭で得られた波形 Fig. 3c では，ひび割れ反射の深さは，ボアホー ルカメラで観察されたひび割れ深さと整合しており，試験によりひ び割れ深さの推定が可能であることを確認できる。一方で，試験で はひび割れの有無の判断に留まっており，ひび割れの程度は十分に は評価できていない。ここで，一般に用いられる，弾性波探査試験 による杭健全性の判定基準 13,14)についても同様に，「健全性が高い と考えられる」,「部分的な損傷の疑いあり」,「杭の全断面に及ぶ損 傷の疑いあり」の 3 項目に大別されるに留まっている。

以上より, 弾性波探査試験による杭の健全性評価の課題について, 次のように整理できる。

1) 試験結果を経験に基づき評価せざるを得ないため, 杭のひび割 れの有無の判断にはばらつきが生じる。

2) 杭のひび割れ深さの推定は可能であるが，ひび割れの程度は十 分には評価できていない。
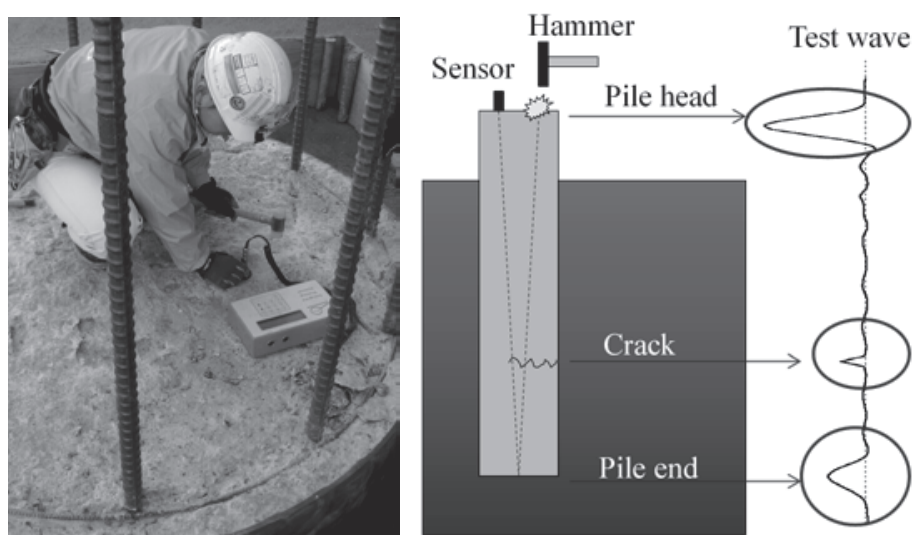

Fig. 1 Outline of pile integrity test (PIT)

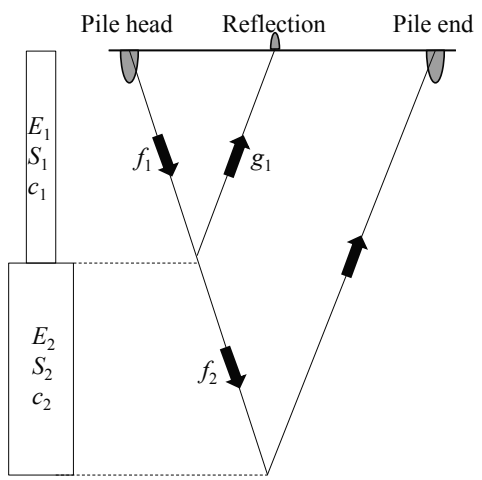

(a) Area increase

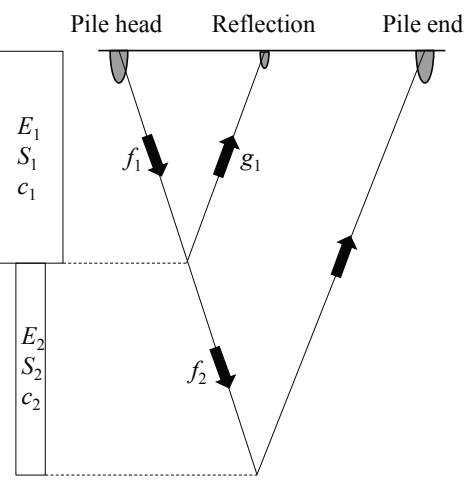

(b) Area decrease (crack)
Fig. 2 Reflection caused by cross-section variation

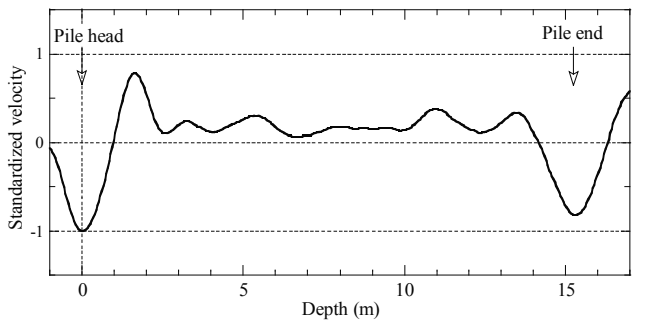

(a) Fine pile ( $\phi 2000 \mathrm{~mm}, L=15.30 \mathrm{~m})$

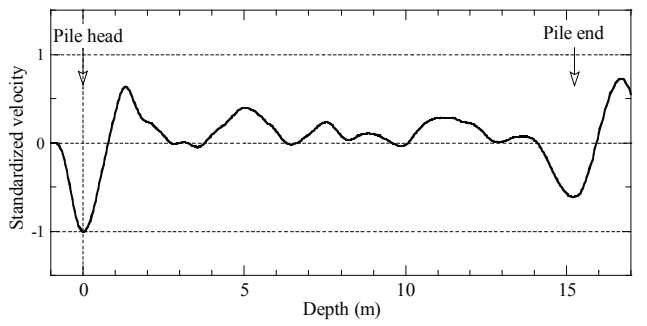

(b) Fine pile $(\phi 2000 \mathrm{~mm}, L=15.34 \mathrm{~m})$

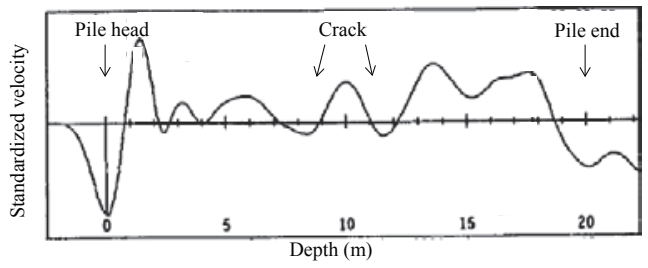

(c) Damaged pile ( $\phi 1700 \mathrm{~mm}, L=17.60 \mathrm{~m})\left(\right.$ based on Mizuno $\left.1996^{8}\right)$ Fig. 3 Test waves of cast-in-place concrete piles obtained from PIT 


\section{3. 杭の弾性波探査試験に関する実験的検討}

2 章では, 弾性波探查試験による杭の健全性評価の課題を示した。 本章では, ひび割れの深さや程度が異なる $\mathrm{PHC}$ 杭に対して弾性波探 查試験を行い, 得られる試験波形の振幅特性と杭のひび割れの大き さとの関係について評価した。

\section{1. 実験概要と曲げ試験結果}

実験概要を Figs. 4, 5, 杭試験体の諸元を Table 1 に示す。PHC T1 （Fig. 4）では, 杭の曲げ試験の荷重段階毎に弾性波探查試験を実施 した。PHC_T2（Fig. 5）では，健全な杭試験体 1 体（T2_1）と，あ らかじめ曲げ試験によりひび割れを生じさせた杭試験体 3 体 （T2_2 4）について, 気中で 2 点支持し弾性波探查試験を実施した。
その後, プレボーリング工法により実地盤に打設し, 再び弾性波探 查試験を実施した ${ }^{15)}$ 。曲げ試験は JIS A 5373 (2010） ${ }^{16)}$ に基づき，2 点支持 2 点載荷方式で行い, 中央載荷曲げスパンは $1 \mathrm{~m}$ とした。杭 のひび割れ幅はクラックスケール等を用いて読み取り，発生したひ び割れの中で最大のひび割れ幅を代表值 $\mathrm{w}$ として採用した。弾性波 探査波形は, 一回の計測につき 4 波計測した。

曲げ試験により得られた杭の曲げモーメントー曲率関係を Fig. 6 に示す。PHC_T1 では, 設計ひび割れ荷重 $M_{c r}$ を超えた $486 \mathrm{kN} * \mathrm{~m}$ で ひび割れが生じ，設計破壊荷重 $M_{u}$ を超えた $684 \mathrm{kN} * \mathrm{~m}$ まで載荷した 段階で，PC 鋼材が切れ除荷した。ひび割れは杭中間部に生じ，載荷 終了後に計測した最大ひび割れ幅は $0.67 \mathrm{~mm}$ であった。PHC_T2_2

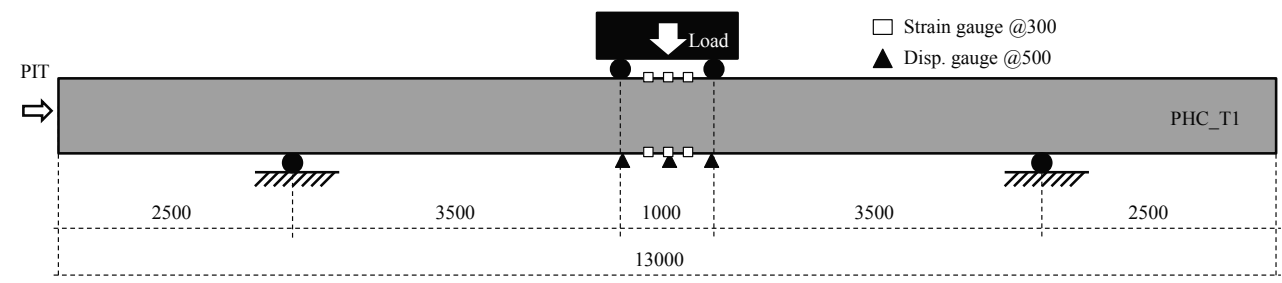

Fig. 4 Test equipment (PHC_T1)
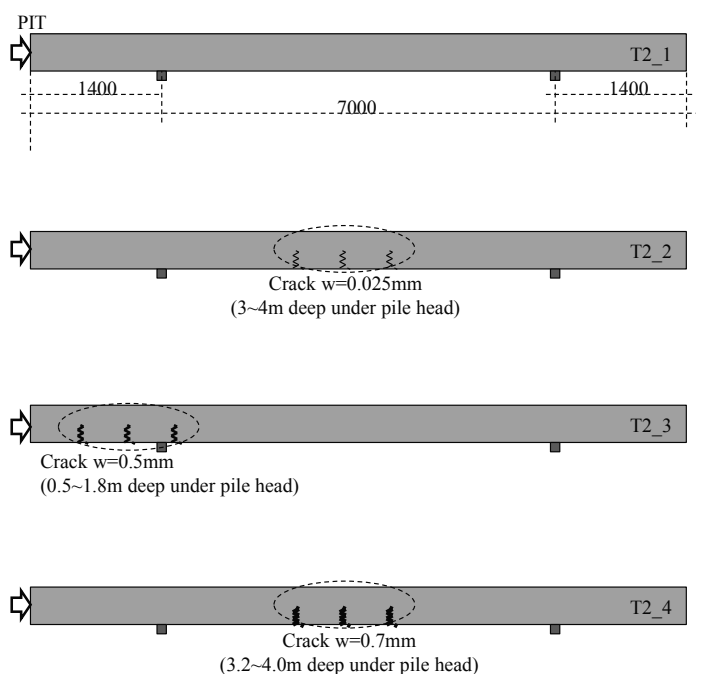

(a) Tests to piles in the air

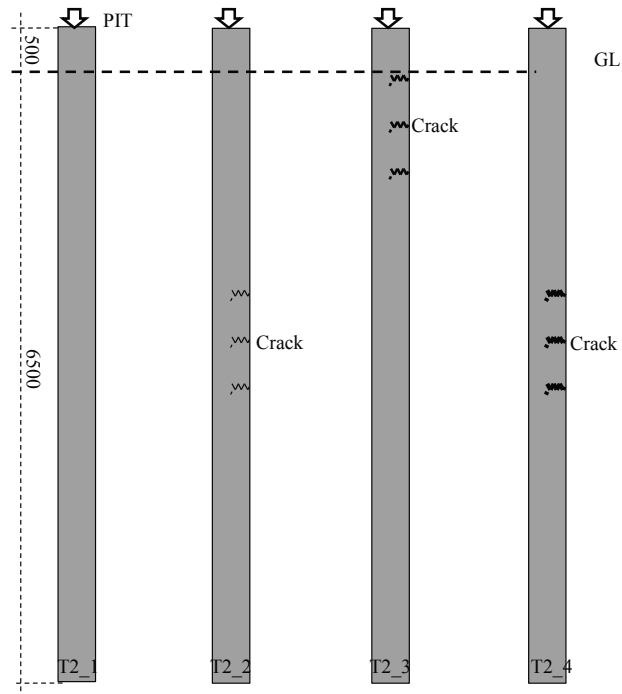

Fig. 5 Test equipment (PHC_T2)

Table 1 Pile specifications

\begin{tabular}{|c|c|c|}
\hline Test case & PHC_T1 & PHC_T2 \\
\hline Pile type & PHC pile & PHC pile \\
\hline Diameter $(\mathrm{mm})$ & 800 & 400 \\
\hline Length $(\mathrm{m})$ & 13 & 7 \\
\hline $\begin{array}{c}\text { Cracking moment } \\
M_{c r}(\mathrm{kN} * \mathrm{~m})\end{array}$ & 392.4 & 56 \\
\hline $\begin{array}{c}\text { Ultimate moment } \\
M_{u}(\mathrm{kN*m})\end{array}$ & 603 & 92 \\
\hline PIT condition & Pile in the air & $\begin{array}{c}\text { Pile in the air } \\
\text { under the ground }\end{array}$ \\
\hline $\begin{array}{c}\text { Number of } \\
\text { PIT waves }\end{array}$ & 24 & 4 \\
\hline $\begin{array}{c}\text { Crack width } \\
\text { w (mm) }\end{array}$ & $0 \sim 0.67$ & $0 \sim 0.7$ \\
\hline
\end{tabular}

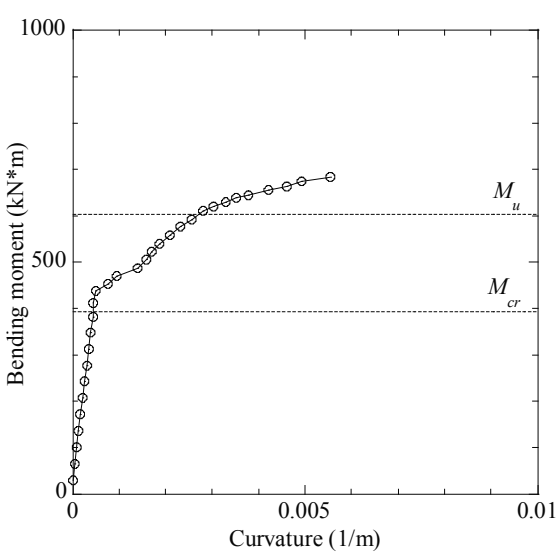

(a) PHC_T1

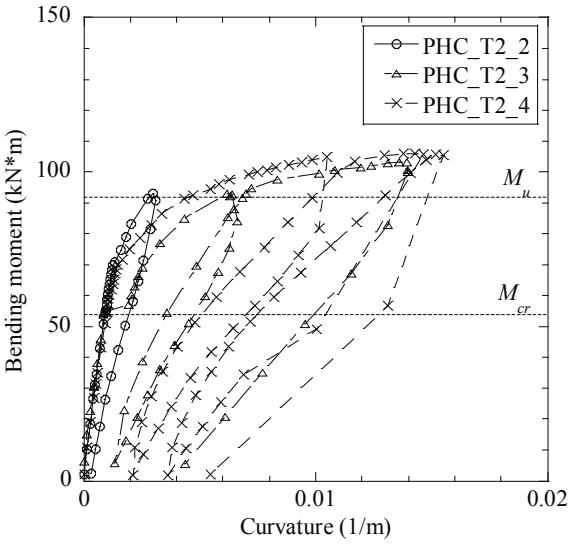

(b) PHC_T2

Fig. 6 Bending moment-curvature curves of piles obtained from bend tests 
では, 設計ひび割れ荷重を超えた $69.4 \mathrm{kN} * \mathrm{~m}$ でひび割れが生じ, 設 計破壊荷重まで載荷したのち除荷した。軽微なひび割れが杭中間部 に生じたが，除荷するとほぼ閉じていた（0.025 mm 幅）。PHC_T2_3 では, 設計破壊荷重を超えた $102.0 \mathrm{kN} * \mathrm{~m}$ まで載荷したのち除荷した。 ひび割れは杭頭部に生じ, 除荷しても閉じずに $0.5 \mathrm{~mm}$ 幅で残った。 PHC_T2_4 では, 設計破壊荷重を大きく超えた $105.0 \mathrm{kN} * \mathrm{~m}$ まで載荷 した段階で，PC 鋼材が切れ除荷した。ひび割れは杭中間部に生じ， 除荷しても閉じずに $0.7 \mathrm{~mm}$ 幅で残った。

\section{2. 弾性波探査試験波形振幅と杭のひび割れの大きさとの関係}

PHC_T1 で得られた弾性波探查試験波形の一例を Fig. 7 に示す。 ひび割れ幅が大きくなるにつれて，ひび割れ反射振幅は大きく，杭 先端反射振幅は小さくなっており, 既往の実験的研究 ${ }^{17,18)}$ で報告さ れた内容とも整合している。この結果を踏まえて, 全試験波形につ いて Fig. 8のように各振幅（b,c）を読み取り, ひび割れ幅との関係 を Fig. 9 に示す。結果にややばらつきはあるが，概ね一様に増減す る傾向を確認できる。ここで, 2 章で示した式(8), (9)によれば, ひ び割れが大きくなると, ひび割れ部の面積 $S_{2}$ は小さくなるため, 反 射率 $R$ は大きくなり，ひび割れ反射振幅 $\mathrm{b}$ も大きくなる。同様に透 過率 $T$ は小さくなり, 杭先端反射振幅 $\mathrm{c}$ も小さくなる。このように, 気中の杭を伝わる弾性波探查試験波形の振幅特性は, 試験の振動理 論とも整合していることから, 反射振幅の大きさにより, 杭のひび 割れの大きさを評価できる可能性がある。

地中の杭を伝わる弾性波探查試験波形は, 地盤減衰の影響により

振幅特性が変化し, 杭先端反射が確認しづらくなる。そのため, 通 常, 杭先端にかけて増幅する指数関数を波形に乗じることで, 杭先 端反射の振幅を確認しやすく寸る増幅処理が行われる ${ }^{14)}$ 。 PHC_T2_3 で得られた試験波形について, 杭先端反射振幅の増幅率 で比較し, Fig. 10 に示す。Fig. 10 中の増幅率 1 倍 (Amplification $\times 1$ と記載）は杭先端反射の振幅を増幅させない場合であり，それに対 して杭先端反射の振幅の大きさが 5,10 倍となるような指数関数を 波形に乗じた結果が，増幅率 5,10 倍（Amplification $\times 5,10$ と記載） である。Fig. 10 より，ひび割れ反射振幅 $\mathrm{b}$ と杭先端反射振幅 $\mathrm{c}$ はど ちらも大きくなるが, その増幅割合は, 杭先端反射振幅 $\mathrm{c}$ の方が大 きいことを確認できる。なお，本試験時は増幅率 5 倍の結果を採用 している。

また，ひび割れが深ければ減衰の影響は大きくなり，振幅特性は 変化する。曲げ試験で設計破壊荷重を超える段階まで載荷し，同程 度のひび割れが生じた地中の杭（PHC_T2_3，4）に対して行った弾 性波探査試験結果について, ひび割れ反射振幅 $\mathrm{b}$ とひび割れ深さと の関係を Fig. 11 に示す。比較のため, PHC_T1 で同程度のひび割れ がある気中の杭に対する試験結果も併せて示している。Fig. 11 より， ひび割れ深さが深くなるにつれて，ひび割れ反射振幅 $\mathrm{b}$ は小さくな る傾向を確認できる。すなわち，ひび割れ反射振幅 $\mathrm{b}$ の大きさが等 しければ，その深さが深いほどひび割れは大きい。これらより，杭 の健全性の定量評価にあたっては, 反射振幅の大きさと, その深さ に係る減衰の影響を評価する必要があると考えられる。

\section{4. 杭の弾性波探査試験に関する解析的検討}

3 章では, 杭の健全性の定量評価にあたっては, 反射振幅の大き さと，その深さに係る減衰の影響を評価する必要があることを実験 結果から示した。本章では, 地中の杭の弾性波探査試験を模擬した 3 次元有限要素法による解析的検討を行い, 得られる波形の振幅特 性についてさらに分析した。
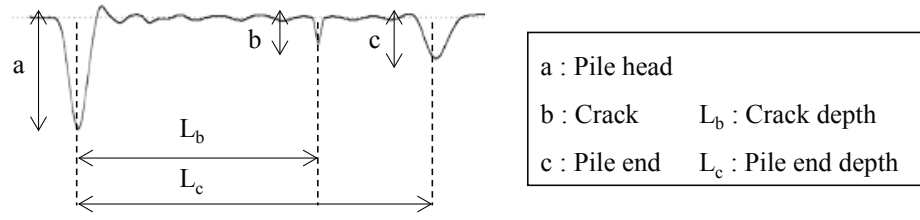

Fig. 8 Values for evaluations of pile soundness

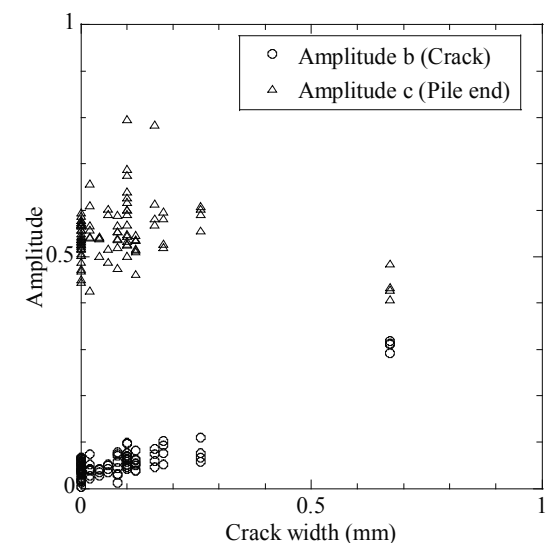

Fig. 9 Relation between amplitudes b, c and crack width

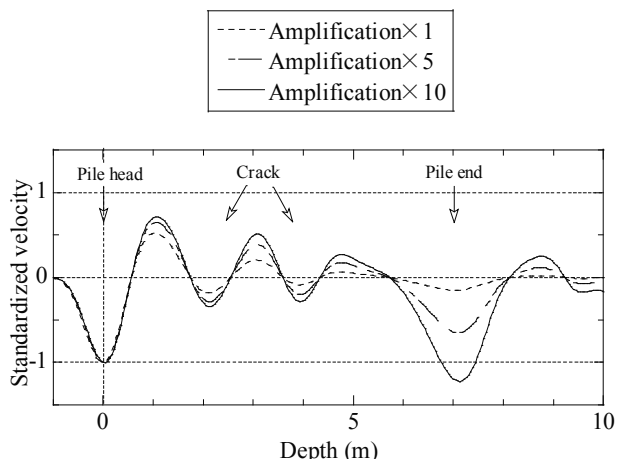

Fig. 10 Effect of amplification on test waves

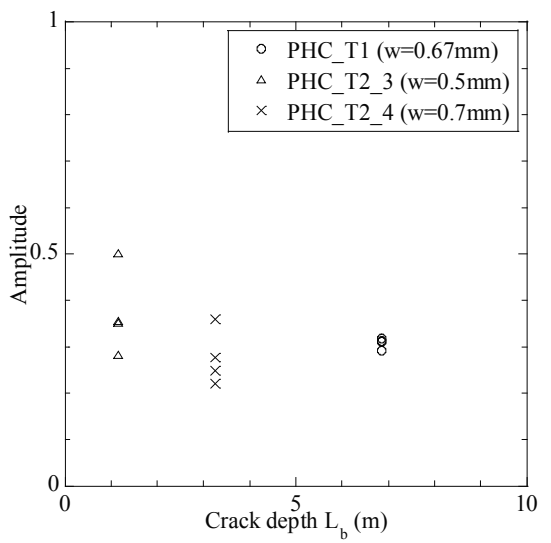

Fig. 11 Relation between amplitude b and crack depth 


\section{1. 検討方法}

5.1 節で述べる実地盤における杭の弾性波探査試験を想定し, 設 定した解析モデルを Fig. 12, 材料定数を Tables 2, 3 に示す。杭と地 盤は 8 節点 3 次元ソリッド要素でモデル化した。地盤は(株)大林組 技術研究所の地盤構成を参考に, 表層地盤と支持地盤の 2 層地盤と し, 深さ方向のメッシュ間隔は $0.2 \mathrm{~m}$ とした。杭は PHC 杭とし, ひ び割れに相当する断面欠損部（メッシュ幅 $0.02 \mathrm{~m}$ ) を設けた。杭の ひび割れ幅はひび割れ長さに比例すると仮定し， 欠損部の幅の代わ りに, Fig. 13 に示寸杭の全断面積に対する欠損部面積の割合 (以下, 断面欠損率 Crack ratio と称する）を用いて，ひび割れを表現した。 杭頭打撃により生じるひずみは微小なため, 杭・地盤ともに弾性と した。杭には内部粘性減衰 $1 \%$ を与え, 地盤側方および底面には粘 性境界を設定した。Fig. 14 に示寸杭頭に入力した加振力は, 弾性波

Table 2 Material properties of pile

\begin{tabular}{|c|c|}
\hline Pile type & PHC pile \\
\hline Diameter $(\mathrm{mm})$ & 400 \\
\hline Length $(\mathrm{m})$ & 15 (embedment is $1 \mathrm{~m})$ \\
\hline Elastic modulus $\left(\mathrm{kN} / \mathrm{m}^{2}\right)$ & $40,000,000$ \\
\hline Density $\left(\mathrm{t} / \mathrm{m}^{3}\right)$ & 2.6 \\
\hline Poisson ratio & 0.200 \\
\hline Crack depth $\mathrm{L}_{\mathrm{b}}$ & $4 \sim 8 \mathrm{~m}$ deep under pile head \\
\hline Crack ratio & $50 \sim 100 \%$ \\
\hline
\end{tabular}

Table 3 Material properties of soil

\begin{tabular}{|c|c|c|}
\hline Soil type & Surface layer & Bearing layer \\
\hline Vs $(\mathrm{m} / \mathrm{s})$ & 130 & 380 \\
\hline Elastic modulus $\left(\mathrm{kN} / \mathrm{m}^{2}\right)$ & 59,900 & 693,000 \\
\hline Density $\left(\mathrm{t} / \mathrm{m}^{3}\right)$ & 1.4 & 2.0 \\
\hline Poisson ratio & 0.265 & 0.199 \\
\hline
\end{tabular}

探査試験でのハンマー加振を想定し，三角波で模擬した。試験に合 わせて, 加振により得られる速度波形を検討対象とした。本解析で は, 後述する振幅増幅処理を行い, フィルター処理は行っていない。

\section{2. 弾性波探査試験波形振幅と断面欠損率との関係}

2 章で示したように, ひび割れがある杭の波形には, 3 つの特徴的 な振幅（杭頭打撃，杭先端反射，ひび割れ反射）が生じる。3 章で の検討と同様に, 各振幅 ( $\mathrm{a}, \mathrm{b}, \mathrm{c})$ を Fig. 8 のように読み取り, 断面 欠損率との関係を Fig. 15 に示す。ここで, 縦軸の b/a は入力に対す る応答の比（ひび割れ反射／杭頭打撃）， b/c は応答同士の比（ひび 割れ反射／杭先端反射）とした。実験と同様に，欠損率が大きくな ると, ひび割れ反射振幅 $\mathrm{b}$ は大きく, 杭先端振幅 $\mathrm{c}$ は小さくなるた め, Fig. 15 に示すように振幅比 b/a, b/c はともに大きくなる。一方 で，同じ欠損率にもかかわらず，欠損深さによる振幅比のばらつき は大きい。これは杭体内部減衰や地盤冕散減衰の影響により, 欠損 深さが深くなると，振幅 $\mathrm{b}$ が小さくなるためと考えられる。

次に, 3.2 節で示した, 地中の杭の弾性波探査試験で行われる振 幅増幅処理を行った場合について検討寸る。この処理は, 地盤逸散 減衰の影響を打ち消寸ためと考えられるが，本解析検討においても 同様に, 指数関数を乗じて振幅を増幅させる処理を行うこととする。 増幅処理を行い得られた振幅比と断面欠損率との関係を Fig. 16 に 示す。ここで, 通常は現場計測時, 杭先端反射の振幅を杭頭打撃の 0.5 倍程度となるよう増幅させるので, 本検討でも試験の実情に合 わせて, $c^{\prime}=0.5 \times \mathrm{a}^{\prime}$ となるよう増幅処理を行った。本解杭では杭の 断面久損に着目した検討を行っており，その久損位置や久損率によ って杭先端反射の振幅の大きさは変化するため, 採用した増幅率は 解析ケースごとに異なる（増幅率 5２0 倍）。なお a' $(=a), b^{\prime}, c^{\prime}$ は増 幅処理後の振幅を示す。これらより, 増幅処理前の Fig. 15 に比べて,

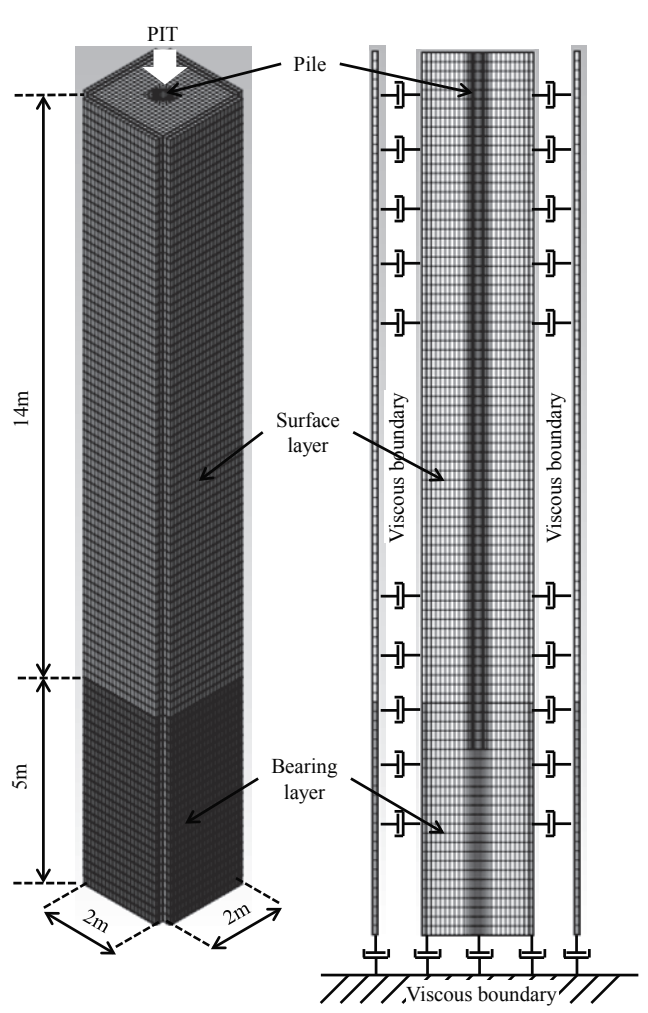

Fig. 12 Analytical model

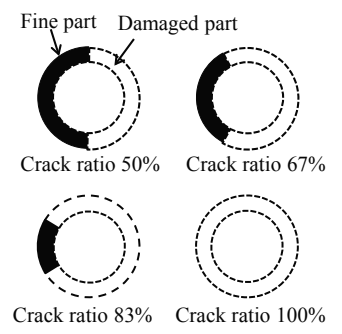

Fig. 13 Cross-section of damaged pile

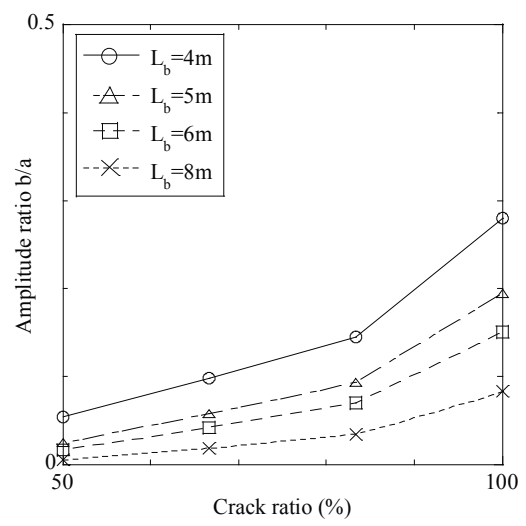

(a) $\mathrm{b} / \mathrm{a}$

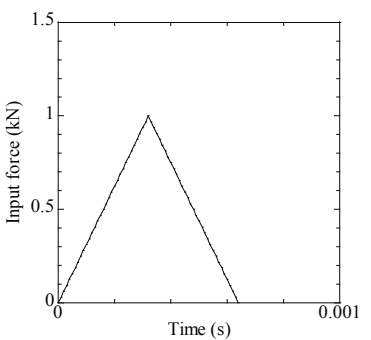

(a) Time history waveform Fig. 14 Input wave

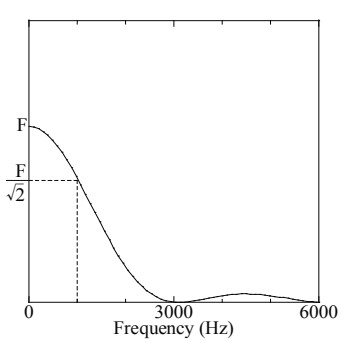

(b) Frequency characteristic

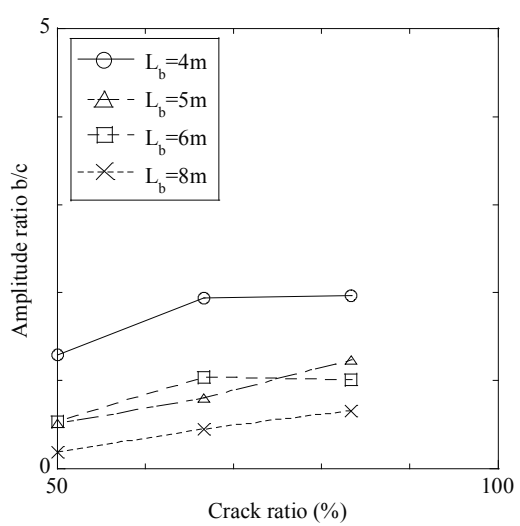

(b) $\mathrm{b} / \mathrm{c}$

Fig. 15 Relation between amplitude ratios b/a, b/c and crack ratio 
指数関数的な増加傾向が直線的な傾向となったことを確認できる。

さらに, 久損深さによる振幅比のばらつきについて検討する。欠 損深さによる振幅比のばらつきは, 主に, 杭体を伝わる弾性波探査 試験波形の減衰に起因寸ると考えられるため, ひび割れ反射振幅 $\mathrm{b}$ の減少に対する, 杭体内部減衰と地盤逸散減衰それぞれの寄与分に ついて, 久損率 $100 \%$ の杭を用い分析した。振幅の総低減率 $r_{p+s}$, 杭 体内部減衰による低減率 $r_{p}$, 地盤逸散減衰による低減率 $r_{s}$ につて, 以下の式(10)-(12)で定義する。

$$
r_{p+s}=v_{g} / v_{0}, \quad r_{p}=v_{a} / v_{0}, \quad r_{s}=r_{p+s} / r_{p}
$$

ここで， $v_{g}$ : 杭（減衰 $1 \%$ ）を地中加振して得られる振幅 $\mathrm{b}, v_{a}$ : 杭（減衰 $1 \%$ ）を気中加振して得られる振幅 $\mathrm{b}, v_{0}$ ：杭体内部減衰や 地盤逸散減衰が無い場合に得られる振幅 $\mathrm{b}$ 。式(10)-(12)により求めた 杭体内部減衰および地盤逸散減衰による低減率と欠損深さとの関係 を Fig. 17 に示す。これより, 欠損深さが深くなるにつれて, 杭体内 部減衰による低減は一次関数的に大きくなること $\left(r_{p}\right)$, 地盤逸散減 衰による低減は指数関数的に大きくなること $\left(r_{s}\right)$ を確認できる。

\section{5. 弾性波探査試験結果に基づく杭健全性評価法の提案}

前章での検討により，杭のひび割れの大きさは，弾性波探查試験 結果における, ひび割れ反射振幅 $\mathrm{b}$ の杭頭打撃振幅 $\mathrm{a}$ および杭先端 反射振幅 $\mathrm{c}$ に対する比率に応じて定まること, および, 地盤逸散減 衰の影響が補正されている場合には，杭体内部減衰の影響を受け，
振幅 $\mathrm{b}$ の深さに比例して定まることを確認できた。これらの結果を もとに, 弾性波探查試験結果に基づく杭健全性評価法として, 以下 の式(13), (14)を提案する。

$$
\begin{aligned}
& \mathrm{B} / \mathrm{A}=\left(\mathrm{b}^{\prime} / \mathrm{a}^{\prime}\right) \times\left(\mathrm{L}_{\mathrm{b}} / \mathrm{L}_{\mathrm{c}}\right) \\
& \mathrm{B} / \mathrm{C}=\left(\mathrm{b}^{\prime} / \mathrm{c}^{\prime}\right) \times\left(\mathrm{L}_{\mathrm{b}} / \mathrm{L}_{\mathrm{c}}\right)
\end{aligned}
$$

B/A, B/C は杭のひび割れの大きさを示す損傷係数であり, 弾性波 探查試験結果を Fig. 8 のように読み取り, 定められる值 $\left(\mathrm{a}, \mathrm{b}, \mathrm{c}, \mathrm{L}_{\mathrm{b}}, \mathrm{L}_{\mathrm{c}}\right)$ により算出する。ここで, $\mathrm{a}$ : 杭頭打撃振幅, $\mathrm{b}:$ ひび割れ反射振幅, $\mathrm{c}$ : 杭先端反射振幅, $\mathrm{L}_{\mathrm{b}}$ : ひび割れ反射の深さ (=欠損深さ), $\mathrm{L}_{\mathrm{c}}$ : 杭先端反射の梁さ (=杭長)。4 章での解析検討結果について, 損傷 係数 B/A，B/C と断面欠損率との関係を Fig. 18 に示す。どの欠損率 においても，欠損深さによるばらつきが抑えられており，損傷係数 B/A，B/C を用いることで，損率を概ね定量的に評価できることを 確認できた。ここでは，久損部が 1 ヶ所の場合の適用方法について 示したが，欠損部が複数ある場合は，欠損部の数だけひび割れ反射 振幅が生じるため，それぞれに対して本評価法を適用する。

\section{6. 実験および実建物での現場計測結果による検証}

5 章では, 弾性波探查試験の結果を用いて, 杭の健全性を合理的 に評価できる指標（損傷係数）を提案した。本章では，提案した損 傷係数について, 損傷杭を用いた実験や実建物での現場計測結果に よる検証を行った。

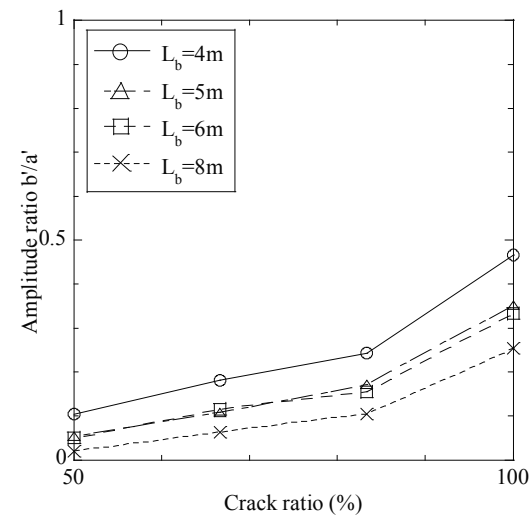

(a) b\%/a'

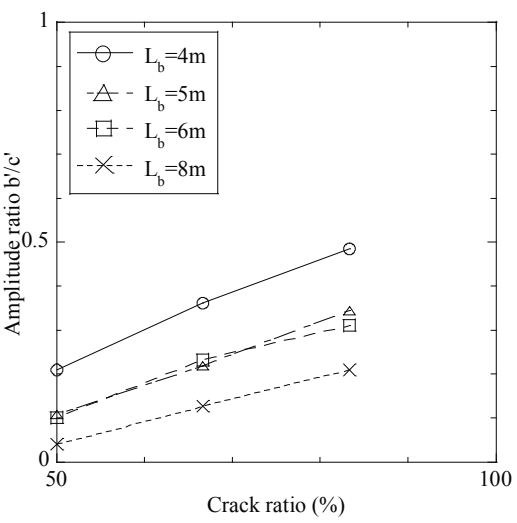

(b) $b \%$ c'

Fig. 16 Relation between amplitude ratios b'/a', b'/c' and crack ratio

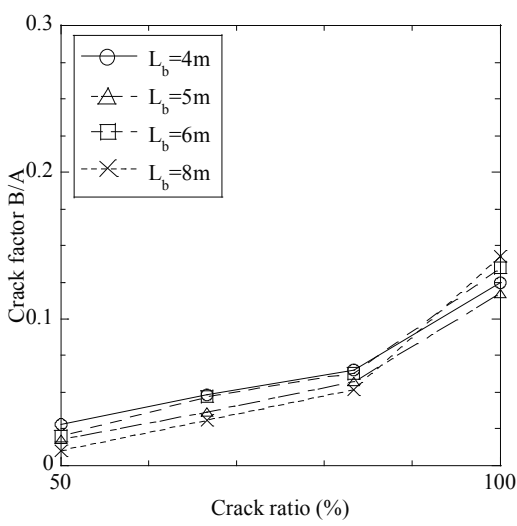

(a) $\mathrm{B} / \mathrm{A}$

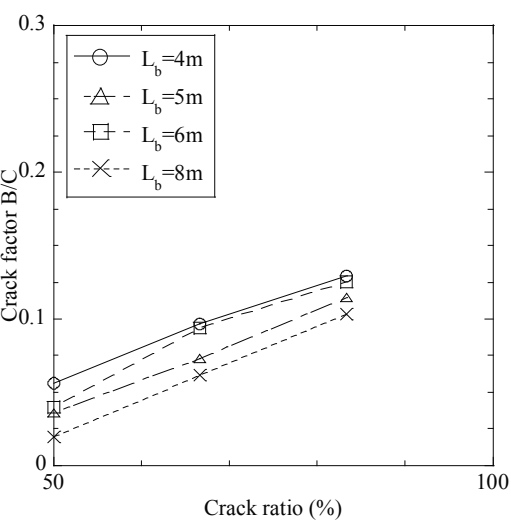

(b) $\mathrm{B} / \mathrm{C}$

Fig. 18 Relation between crack factors $B / A, B / C$ and crack ratio

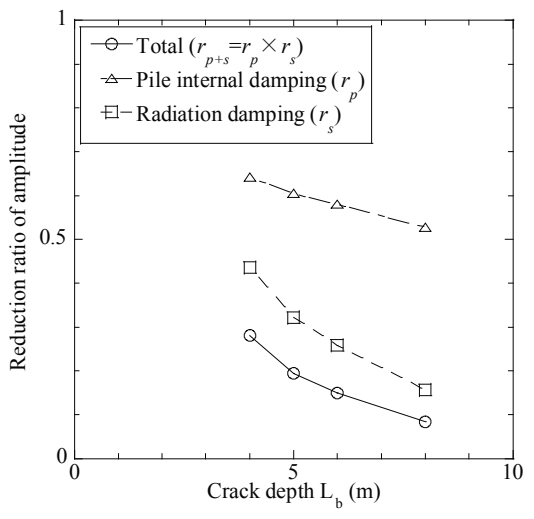

Fig. 17 Reduction ratios of amplitude

Table 4 Test cases

\begin{tabular}{|c|c|c|c|}
\hline Test case & PHC_T1 & PHC_T2 & RC_T1 \\
\hline Pile type & PHC pile & PHC pile & $\begin{array}{c}\text { Cast-in-place } \\
\text { concrete pile }\end{array}$ \\
\hline Diameter (mm) & 800 & 400 & 400 \\
\hline Length (m) & 13 & 7 & 3 \\
\hline PIT condition & $\begin{array}{c}\text { Pile } \\
\text { in the air }\end{array}$ & $\begin{array}{c}\text { Pile in the air } \\
\text { under the ground }\end{array}$ & $\begin{array}{c}\text { Pile } \\
\text { in the air }\end{array}$ \\
\hline $\begin{array}{c}\text { Number of } \\
\text { PIT waves }\end{array}$ & 24 & 4 & 27 \\
\hline $\begin{array}{c}\text { Crack width } \\
\text { w (mm) }\end{array}$ & $0 \sim 0.67$ & $0 \sim 0.7$ & $0 \sim 0.57$ \\
\hline
\end{tabular}




\section{1. 損傷杭を用いた実験による検証}

検証に用いた実験結果の一覧を Table 4 に示す。PHC_T1, 2 は 3 章 で示した実験 (Figs. 4, 5) である。Fig. 19 に示す RC_T1 では, PHC_T1 と同様に, 杭の曲げ試験の荷重段階毎に弾性波探查試験を実施して おり, 杭試験体は圧縮強度 $\sigma=33.1 \mathrm{~N} / \mathrm{mm}^{2}$, 弾性係数 $E=3.06 \times 10^{4} \mathrm{~N} / \mathrm{mm}^{2}$, 全主筋比 $\mathrm{P}_{\mathrm{g}}=2.74 \%$, せん断補強筋比 $\mathrm{pw}=0.22 \%$ である。他の実 験条件は 3 章で述べた通りである。なお, PHC_T2 の地中加振時に は 3.2 節で示した振幅増幅処理（増幅率 5 倍）を行い, フィルター 処理は行っていない。弾性波探查試験により得られた波形について, Fig. 8 のように各振幅 $(\mathrm{a}, \mathrm{b}, \mathrm{c})$ とその深さ $\left(\mathrm{L}_{\mathrm{b}}, \mathrm{L}_{\mathrm{c}}\right)$ を読み取り, 提 案式(13), (14)により損傷係数 B/A, B/C を算出した。 B/A, B/C と杭の ひび割れ幅との関係を Figs. 20a, 20b, 21a, 21b に示す。ここで, 基礎 指針 ${ }^{19)}$ やコンクリート関連の指針 ${ }^{20,21)}$ を参考に, 場所打ち $\mathrm{RC}$ 杭の

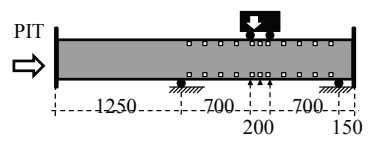

(a) Full view

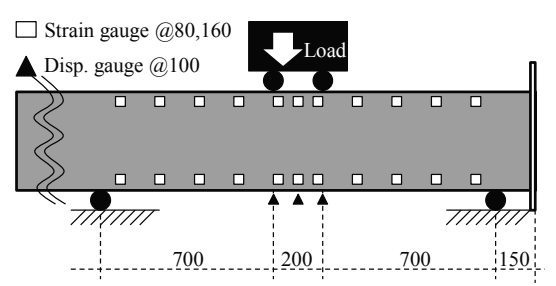

(b) Partial enlarged view $(\times 2.5)$

Fig. 19 Test equipment (RC_T1)
性能に影響しないひび割れ幅を $0.2 \mathrm{~mm}$ とした。PHC 杭については, ここでは $0.1 \mathrm{~mm}$ とした。図より, どちらの杭種でもばらつきがある ものの，損傷係数が大きくなるにつれて，ひび割れ幅も大きくなる 傾向を確認できる。このばらつきを減少させるために，横軸に損傷 係数 B/A，縦軸に損傷係数 B/C をとった結果を Figs. 20c, 20d, 21c に 示寸。Fig. 21c の場所打ち RC 杭では，ばらつきが抑えられ，概ね対 角線上に分布した結果を得た。また，杭のひび割れ幅が大きくなる につれて, 図の原点から遠ざかる位置に分布するようになる傾向も 確認できる。なお，図の網掛け部分は，前述した杭性能に影響しな

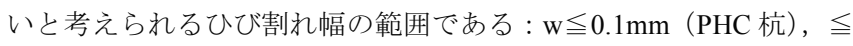
$0.2 \mathrm{~mm}$ (場所打ち $\mathrm{RC}$ 杭)。

PHC 杭では, Fig. 20c の範囲では概ね対角線状に分布しているが, Fig. 20d の範囲ではやや外れている結果 (PHC_T2 の地中加振時, 増 幅率 5 倍, 図中では Amplification $\times 5$ と記載）もあり, この要因に ついて分析する。Fig. 20d には, 比較のため, 振幅を増幅させない 場合（増幅率 1 倍, 図中では Amplification $\times 1$ と記載）の結果も併 せて示している。振幅増幅処理により, ひび割れ反射振幅 $\mathrm{b}$ と杭先 端反射振幅 $\mathrm{c}$ はどちらも大きくなるが，その増幅割合は，杭先端反 射振幅 $\mathrm{c}$ の方が大きいため, 増幅処理をしていない結果に比べて, 算出される損傷係数 $\mathrm{B} / \mathrm{A}$ は大きく, $\mathrm{B} / \mathrm{C}$ は小さくなる。すなわち, 増幅処理を行うことで, $\mathrm{B} / \mathrm{A}-\mathrm{B} / \mathrm{C}$ 関係図の左上 (Amplification $\times 1$ と記載した範囲）から，対角線に近づく方向である右下 (Amplification $\times 5$ と記載した範囲) に分布位置が移動する。しかし, 試験装置の仕様上，増幅率を細かく設定できないため，対角線状に うまく分布せず，ばらついてしまうと考えられる。一方で，Fig. 20d での検討によれば, このばらつきを考慮しても, 図中に示した性能

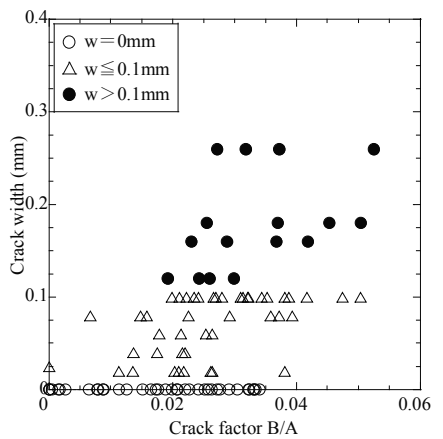

(a) $\mathrm{B} / \mathrm{A}$

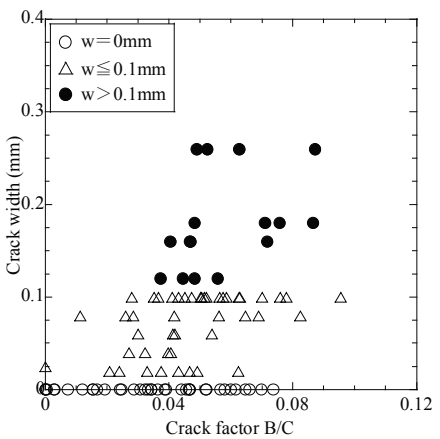

(b) $\mathrm{B} / \mathrm{C}$

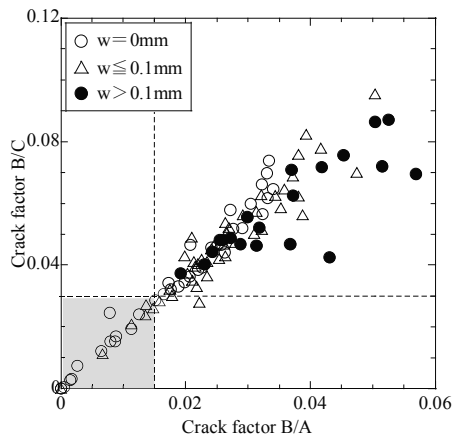

(c) $\mathrm{B} / \mathrm{A}-\mathrm{B} / \mathrm{C}$ relation $(\mathrm{B} / \mathrm{A}<0.06)$

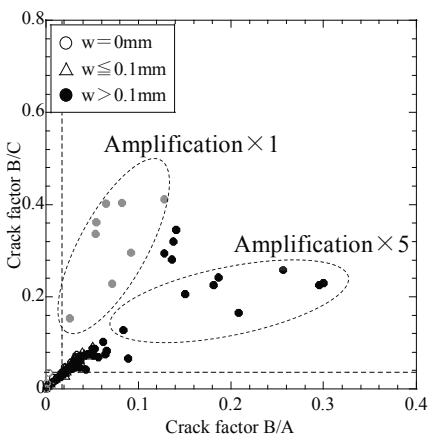

(d) $\mathrm{B} / \mathrm{A}-\mathrm{B} / \mathrm{C}$ relation $(\mathrm{B} / \mathrm{A}<0.4)$

Fig. 20 Evaluation of crack width of PHC piles using crack factors $B / A, B / C$

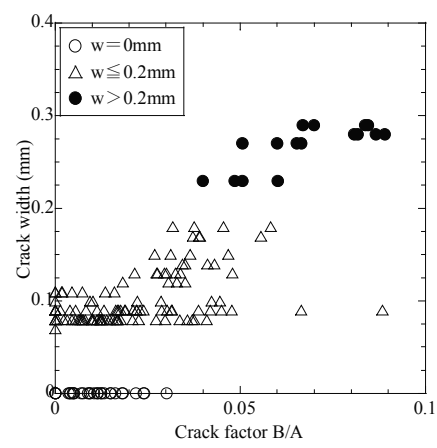

(a) $\mathrm{B} / \mathrm{A}$

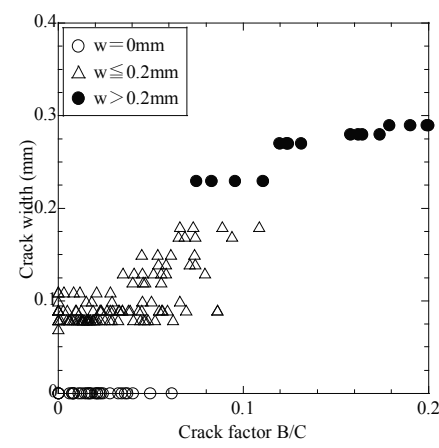

(b) $\mathrm{B} / \mathrm{C}$

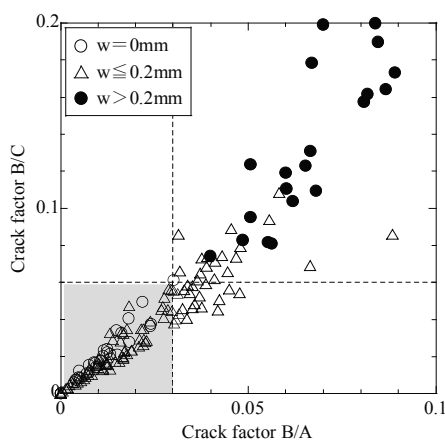

(c) $\mathrm{B} / \mathrm{A}-\mathrm{B} / \mathrm{C}$ relation

Fig. 21 Evaluation of crack width of cast-in-place concrete piles using crack factors B/A, B/C 
に影響しないと考えられる範囲内（左下の網掛け範囲）には分布し ないことを確認できるため, 損傷係数を用いた提案手法は有効であ ると考えられる。

\section{2. 実建物での現場計測結果による検証}

実験により構築した Figs. 20c, 20d, 21c について, 実建物での現場 計測結果により検証する。現場計測の一覧を Table 5, 検証結果を Fig. 22 に示寸。これらは, 施工中または供用中の建物の杭や, 1995 年兵庫県南部地震で被災した建物の杭に対して行われた弾性波探査 試験結果 ${ }^{4-9,22)}$ である。併せて, 杭頭目視やボアホールカメラによる 杭のひび割れ観察も行われており, ひび割れの位置（杭頭からの鉛 直方向深さ）とその幅が明らかになっている。また, 振幅増幅率と フィルター処理の有無については Table 5 中に示している。

Figs. 22a, 22c より, ひび割れのない又は微小なケースを示寸白抜 きの結果は図の左下の範囲(杭性能に影響しないと考えられる範囲) の内側に分布し、ひび割れが軽微なケースを示す黒塗りの結果は範 囲外に分布している。このように, 実建物での現場計測結果より算 出した損傷係数の分布は, 実験結果と概ね調和的であるが, そのば らつきは実験結果に比べて大きい。このばらつきの要因について, 個々の現場計測事例について分析する。PHC_M1〜4, RC_M4では, ひび割れのある杭に対して試験が行われ, ひび割れ反射振幅を確認 しやすい増幅率が採用されたと考えられる。RC_M3 も同様であるが， 他の事例に比べひび割れ幅が大きいにもかかわらず，同じ増幅率を 採用しており, やや過大な值であると考えられる。一方で, RC_M1 では, ひび割れが無い杭に対して試験が行われ，杭先端反射振幅を 確認しやすい増幅率が採用されている。このように, 現場計測事例
によって増幅率の設定方針が異なることが，前述した分布のばらつ きの要因と考えられる。

そこで，現場計測についても実験と同様に，杭先端反射の振幅が 確認しやすいよう増幅処理を行うこととし，ここでは杭先端反射の 振幅が杭頭打撃の 0.5 倍程度となるよう増幅率を補正し, 結果につ いて検討した。前述したように，ひび割れ反射振幅を確認しやすい 増幅率を採用していた PHC_M1〜4, RC_M4 については増幅率 50 倍 やや過大な増幅率を採用していた RC_M3 については増幅率 5 倍と 補正を行い，杭先端反射振幅を確認するため増幅率を設定していた RC_M1 と，増幅率に関する記載が見当たらないRC_M2 については 補正を行っていない。再評価した損傷係数の分布を Figs. 22b, 22d に 示す。増幅率を補正した Figs. 22b, 22d では, Figs. 22a, 22c に比べ分 布のばらつきが抑えられ，実験結果と同様に概ね対角線状に分布す るようになったことを確認できる。また，図の左下に示した杭性能 に影響しないと考えられる範囲との対応について, ひび割れのない 又は微小なケースを示す白抜きの結果は範囲内に, ひび割れが軽微 なケースを示寸黒狳りの結果は範囲外に, 増幅率を補正しても変わ らずに分布している。この結果より, 損傷係数の分布は振幅の増幅 率によりばらつく場合もあるが，杭性能への影響の有無を評価する 上では，その影響は小さいと考えられる。さらに，フィルター処理 (移動平均処理 ${ }^{14)}$ ) の影響について, フィルター処理により損傷係 数が小さめに評価されることが懸念されるが，今回検証に用いた現 場計測結果のうち処理を行ったデータの中で，ひび割れがあるにも かかわらず，図の左下に示した杭性能に影響しないと考えられる範 囲内に分布した結果はない（Fig. 22）。この結果より，杭性能への影

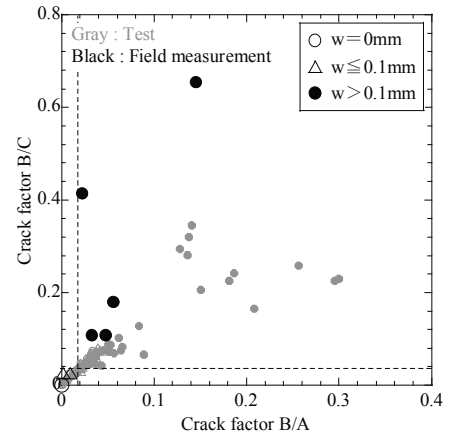

(a) PHC pile

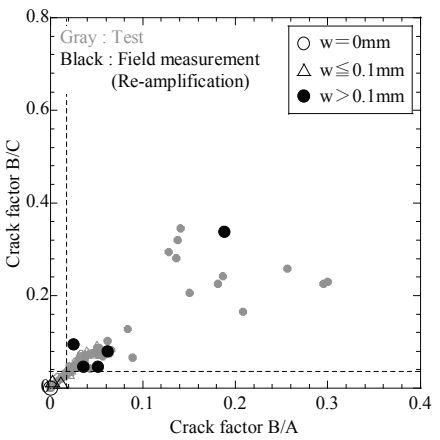

(b) Re-amplification

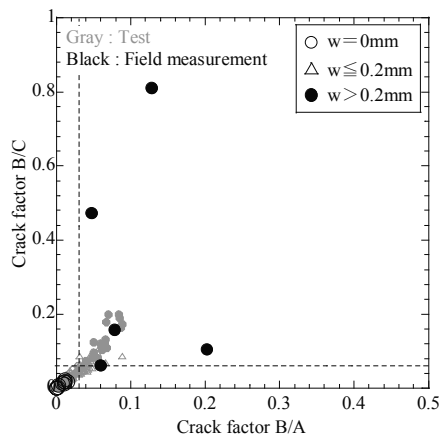

(c) Cast-in-place concrete pile

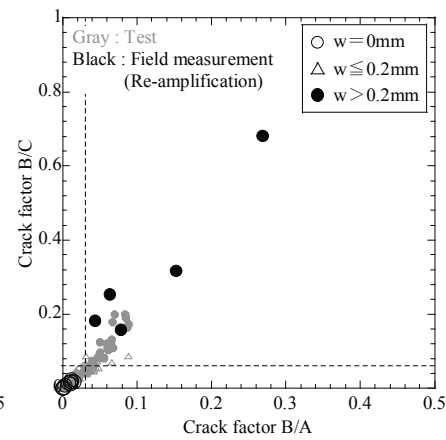

(d) Re-amplification

Fig. 22 Inspection of tests' $B / A-B / C$ relation using field measurements

Table 5 Field measurement cases

\begin{tabular}{|c|c|c|c|c|c|c|c|c|}
\hline Measurement case & PHC_M1 & PHC_M2 & PHC_M3 & PHC_M4 & RC_M1 & RC_M2 & RC_M3 & RC_M4 \\
\hline Pile type & PHC pile & PHC pile & PHC pile & PHC pile & $\begin{array}{l}\text { Cast-in-place } \\
\text { concrete pile }\end{array}$ & $\begin{array}{l}\text { Cast-in-place } \\
\text { concrete pile }\end{array}$ & $\begin{array}{l}\text { Cast-in-place } \\
\text { concrete pile }\end{array}$ & $\begin{array}{l}\text { Cast-in-place } \\
\text { concrete pile }\end{array}$ \\
\hline Diameter (mm) & 450 & 450 & 450 & 500 & 2000 & 1700 & 1000 & 1200 \\
\hline Length $(\mathrm{m})$ & $15 \sim 16$ & 35 & 17 & 33 & 15 & 18 & 35 & 29 \\
\hline PIT condition & $\begin{array}{l}\text { Pile } \\
\text { under the ground }\end{array}$ & $\begin{array}{c}\text { Pile } \\
\text { under the ground }\end{array}$ & $\begin{array}{c}\text { Pile } \\
\text { under the ground }\end{array}$ & $\begin{array}{c}\text { Pile } \\
\text { under the ground }\end{array}$ & $\begin{array}{c}\text { Pile } \\
\text { under the ground }\end{array}$ & $\begin{array}{c}\text { Pile } \\
\text { under the ground }\end{array}$ & $\begin{array}{c}\text { Pile } \\
\text { under the ground }\end{array}$ & $\begin{array}{l}\text { Pile } \\
\text { under the ground }\end{array}$ \\
\hline Number of PIT waves & 4 & 2 & 1 & 2 & 3 & 1 & 2 & 2 \\
\hline Crack width w (mm) & $0 \sim 0.5$ & 0.5 & $0.1 \sim 0.2$ & $0 \sim 0.5$ & 0 & 1.0 & $0.6 \sim 1.9$ & 1.0 \\
\hline Amplification* & $\times 20$ & $\times 20$ & $\times 20$ & $\times 10$ & $\times 10$ & - & $\times 20$ & $\times 20$ \\
\hline Filtering* & $\bigcirc$ & 0 & $\times$ & $\times$ & $x$ & - & $\bigcirc$ & - \\
\hline
\end{tabular}

* $\bigcirc$ : Filtering, $\times$ : No filtering, - : No description of amplification or filtering 
響の有無を評価する上では，フィルター処理の影響も小さいと考え られる。

\section{7. 結論}

既存杭の再利用時の健全性評価に用いられる弾性波探査試験の有 用性を高めるため, 試験結果の分析や 3 次元有限要素法を用いた解 析的な検討を行い, 試験により得られる波形の振幅特性について評 価した。次に，それらの結果に基づいて，弾性波探查試験の結果を 用いて，杭の健全性を合理的に評価できる指標（損傷係数）を新た に提案した。さらに, 提案した損傷係数について, 損傷杭を用いた 実験や実建物での現場計測結果により妥当性を検証した。以下に得 られた知見を示す。

1) 実験とそのシミュレーション解析により, 杭のひび割れの大き さは, 弾性波探查試験波形における, ひび割れ反射振幅の杭頭 打撃振幅および杭先端反射振幅に対する比率に応じて定まる ことを示した。

2) さらに, 試験時に地盤逸散減衰の影響が補正されている場合に は, 杭体内部減衰の影響を受け, 杭のひび割れの大きさは, ひ び割れ反射振幅の深さに比例して定まることを示した。

3) 上記を考慮し提案した損傷係数は, 杭のひび割れの大きさを示 す指標であり，弾性波探査試験波形から各振幅の大きさとその 深さを読み取り定めた值を用いて算出する。

4) 実建物での現場計測時には, 試験波形に対して振幅増幅処理や フィルター処理を行うことにより, 振幅特性が変化する場合が ある。この場合, 算出される損傷倸数の分布もばらつくが，杭 性能への影響の有無を評価する上では, そのばらつきの影響は 小さいことを確かめ，提案手法の妥当性を確認した。

今後も継続的に，実建物での現場計測を行い，提案手法による杭 健全性の評価精度を向上させていきたいと考えている。

\section{謝辞}

本研究を行うにあたり, 日本大学の安達俊夫教授, 東海大学の藤 井衛教授より貴重なご助言を賜りました。本実験・現場計測を実施 するにあたり, 三谷セキサン(株), (株)東京ソイルリサーチの関係各 位には多大なるご協力を頂きました。記して謝意を表します。
1) 建築業協会 : 既存杭利用の手引き, 2003.2 .

2) 阿部秋男：既存杭の再利用のための調査・診断技術，基礎工, Vol.33, No.4, pp.21 24, 2005.4.

3) 阿部秋男：杭体の健全性試験の動向, 基礎工, Vol.41, No.8, pp.22 25, 2013.8 .

4) コンクリートパイル建設技術協会，コンクリートポール・パイル協会： 兵庫県南部地震被害調査報告書 (その 3), 1996.5.

5) コンクリートパイル建設技術協会，コンクリートポール・パイル協会： 兵庫県南部地震被害調査報告書（その4), 1997.3.

6) 阪神・淡路大震災調査報告編集委員会 : 阪神・淡路大震災調査報告 建築 編一 4 木造建築物・建築基礎構造, 日本建築学会, 1998.3.

7）黒木康文，渡辺則雄，森利弘：兵庫県南部地震で被災した建物の杭基礎 被害調査その 1 2, 日本建築学会大会学術講演梗概集, 構造 I, pp.445-448, 2004.8

8) 水野二十一，渡辺則雄，佐藤玲圭，濱田尚人：1995 年兵庫県南部地震に おける場所打ち杭の一被害事例と考察 その 1 3, 日本建築学会大会学 術講演梗概集，構造 I , pp.609-614， 1996.9 .

9) 風早佳子，林隆浩，小野日出男，田中伸治：非破壊試験法を適用した兵 庫県南部地震によるコンクリート基礎杭の被害調査報告（その 1 2 ）, 第 31 回地盤工学研究発表会, pp.1683-1686, 1996.7.

10）総合土木研究所：既存基礎の再利用技術，基礎工, Vol.33, No.4, 2005.4.

11）総合土木研究所：既存基礎の利活用，基礎工，Vol.39，No.2，2011.2.

12) 柴田明徳: 最新 耐震構造解析 第 2 版, 2003.

13）建設省土木研究所ほか：インティグリティ試験を用いた橋梁基礎の損傷 調査法マニュアル（案），1999.3.

14）構造法令研究会 : 既存杭等再使用の設計マニュアル (案), 2008.

15）勝二理智, 藤森健史：実大載荷実験に基づく損傷杭の水平抵抗評価，日 本建築学会構造系論文集, Vol.79, No.705, pp.1637-1645, 2014.11.

16）日本工業規格：JIS A 5373 （2010）プレキャストプレストレストコンクリ 一ト製品.

17）鈴木裕之，二木幹夫，中川宏人：コンクリート杭の健全性試験に関する 基礎的検討, 日本建築学会大会学術講演梗概集，構造 I , pp.1591-1592, 1994.9.

18）山鼻常昭, 加倉井正昭, 山下清, 土屋富男, 福原拓平 : PHC 杭を用いた 低ひずみ非破壊試験に関する基本実験，日本建築学会大会学術講演梗概 集，構造 I , pp.1593-1594，1994.9.

19) 日本建築学会：建築基礎構造設計指針，2001.

20) 日本コンクリート工学協会 : コンクリートのひびわれ調査・補修指針, 1980.

21）日本建築学会：鉄筋コンクリート造建築物の耐久性調査・診断および補 修指針（案）・同解説, 1997 .

22）榎本雅夫, 土谷尚, 森田悠紀雄, 田中勉 : 非破壊試験（Pile Integrity Tests） を用いた杭の損傷度調查, 第 31 回地盤工学研究発表会, pp.443-444, 1996.7. 


\section{REASONABLE EVALUATION OF PILE SOUNDNESS \\ BASED ON PILE INTEGRITY TEST}

\section{Michito SHOJI* and Takeshi FUJIMORI**}

* Technical Research Institute, OBAYASHI CORPORATION, M.Eng.

Existing piles can be used when a building is being rebuilt as these piles can reduce construction costs and wastes. Prior to the reuse of the existing piles, they are inspected using the pile integrity test (PIT) to judge whether they are appropriate for reuse. PIT is the most effective test to inspect pile soundness because of its low cost and convenience. Whether the piles are cracked and where the crack occurs in the piles can be roughly determined using PIT. This evaluation heavily depends on the experience of PIT examiners. Therefore, the evaluation can differ from examiner to examiner. Thus, this paper describes the objective and quantitative evaluation method for pile soundness using PIT.

First, PITs of damaged piles with cracks are conducted to investigate the relation between the size of pile crack and the amplitude height of crack reflection of PIT waves. Prior to the tests, the piles are subjected to bend tests to confirm the size and depth of cracks Next, analyses using three-dimensional finite element method are conducted to investigate the effects of pile internal damping and radiation damping on the amplitude height of the crack reflection. Considering the amplitude characteristics of PIT waves, we propose new indexes (we call "crack factors") that can evaluate pile soundness reasonably. Finally, using field measurements in buildings, the proposed crack factors are inspected to judge whether they are effective for reuse. Most of the buildings considered for the study are either under construction, in service or damaged by the 1995 Hyogoken-Nanbu Earthquake.

The major findings of the study are summarized as follows. 1) The size of pile crack depends on the amplitude ratios b/a and b/c calculated from the quantified values of the amplitude characteristics of PIT waves (see Fig. 9). In this paper, b/a is the ratio of amplitude height of crack reflection to the pile head input, and b/c is the ratio of amplitude height of crack reflection to the pile end reflection. 2) The amplitude heights of PIT waves of piles under the ground are smaller than those for piles in the air because of pile internal damping and radiation damping. When the amplitude heights are enlarged to offset radiation damping, the size of pile crack is in proportion to the depth of crack reflection. This is because when the crack depth is deeper to its pile end, the effect of pile internal damping gets larger and the reduction ratio of amplitude increases linearly (see Fig. 17). 3) Considering the above findings of the amplitude characteristics of PIT waves, we propose the crack factors B/A and B/C in the equations (13) and (14). The size of pile crack can be evaluated using the crack factors (see Figs. 20c, 20d, 21c). The crack factors are calculated from five quantified values of the amplitude characteristics: i) the amplitude height of pile head input "a", ii) the amplitude height of crack reflection "b", iii) the amplitude height of pile end reflection "c", iv) crack depth " $L_{b}$ ", and v) pile end depth " $L_{c}$ ". 4) The distributions of the crack factors based on tests and analyses are consistent with the distributions based on field measurement in buildings (see Fig. 22). 